\title{
Big Data in Smart Energy Systems: A Critical Review
}

Keziban Seçkin Codal, Ankara Yildirim Beyazit University, Department of Management Information Systems, Assistant Professor, kseckin@ybu.edu.tr, ORCID: 0000-0003-1967-7751

İzzet Arn, Social Sciences University of Ankara, Department of Energy Economics and Management, Assistant Professor, izzet.ari@asbu.edu.tr, ORCID: 0000-0002-6117-3605

H. Kemal İlter, Ankara Yildirim Beyazit University, Department of Management Information Systems, Associate Professor, kilter@ybu.edu.tr, ORCID: 0000-0002-6359-9976

ABSTRACT

Keywords : : Smart Energy, Smart Energy Systems, Energy Big Data, Data Analytics, Climate Change

\section{Akıllı Enerji Sistemlerinde Büyük Veri: Eleştirel Bir İnceleme}

$\ddot{O Z Z}$

Içerik İklim değiş̧ikliği yadsınamaz bir gerçektir. Seragazı emisyonlarının üçte ikisinin enerji sektöründen kaynaklandığı düşünüldüğünde, dünya enerji sisteminin yenilenebilir enerji kaynaklarıyla dönüştürü̈lmesi ve enerji verimliliğinin sürekli artırılması beklenmektedir. Enerjiye bağlı karbondioksit emisyonlarının azaltılması, enerjide dönüşümün gereğidir. Enerji sistemlerindeki büyük veriler, hem uyarlanabilir kapasitenin değerlendirilmesinde hem de enerji talebini ve arzını yönetmek için daha akillıca yatırım yapılmasında çok önemli bir rol oynamaktadır. Gerçekten de, akıll enerji şebekesinin ve sayaçların akıll enerji sistemleri üzerindeki etkisi, karar vericilere enerji üretimi, tüketimi ve toplulukların dönüştürme konusunda yardımcı olmaktadır. Bu çalışma, büyük veri ve akıll enerji sistemlerini değerlendirmek için literatürü gözden geçirmekte ve bölgesel perspektife, döneme, 
disiplinlere, büyük veri özelliklerine ve kullanılan veri analizlerine göre eleştirilmektedir. Eleştirel inceleme mevcut temalara ayrılmıştır. Sonuçlar, akıllı enerji literatüründeki büyük verinin özellikleri ve akıll enerji yaklaşımlarının geleceğini dikkate alan ve veri analizi tekniği kullanan bilimsel çalışmaları içeren konuları ele almaktadır. Akıllı enerji sistemlerindeki büyük verilere ilişkin yazılar umut verici olmakla birlikte disiplinler arası kapsamlı çalışmalar yoluyla konuyu genişletmek zorunludur.

\section{Anahtar : Akıllı Enerji, Akılı Enerji Sistemleri, Büyük Enerji Verileri, Veri Analizi, Iklim Kelimeler Değişikliği}

\section{INTRODUCTION}

The Industrial Revolution has permanently changed economies and society in terms of consumption, production patterns, mass production, fossil fuel combustion, various manufactured goods, and society's welfare. Globally, energy use represents the largest source of greenhouse gas emissions from human activities. Approximately two-thirds of global greenhouse gas emissions are associated with burning fossil fuels for heating, electricity, transport, and industrial energy (EEA, 2019). Energy production and use have a significant impact on the climate, and vice versa. Climate change can change our energy production potential and energy needs. For example, warmer temperatures increase the demand for energy for cooling in summer, while reducing the demand for heating in winter (EEA, 2019).

The existing energy infrastructure, new infrastructure, and future planning should consider emerging climate conditions and their impact on the design, construction, operation, and maintenance (Ebinger and Vergara, 2011). Investments in the energy sector can provide lowcost alternatives to fossil fuel-based energy by transforming power generation, transportation, and other energy uses on both supply and demand sides. In the coming years, more resilience to the climate change impact will be required to ensure the energy sector's technical viability and ability to meet the increasing energy demand cost-effectively (GCF, 2019).

Nations take urgent holistic action using their economic strength to dominate the transition to a low-carbon economy to prevent the adverse effects of climate change at a global level (Climate Transparency, 2018). The German government has promised that by 2050 at least $80 \%$ of the country's electricity will come from renewables (SRU, 2011). According to Wilson, in 2016, just $9.3 \%$ of British electricity was generated from coal, down from more than $40 \%$ in 2012 (The Conversation, 2018). A new approach may improve the capacity building of energy come from renewables. The energy sector depends on optimization and predictions: energy production, energy grid balancing (smart grid), and consumption habits (Jucikas, 2017). The translation of energy from conventional to renewable energy is generated a new discussion. Researchers discuss machine learning applications, neural network approaches, and artificial 
intelligence in modeling power generation predictions. Department of Energy ("Annual Energy Outlook 2019") manages the Watt-sun project that leverages new data processing technologies and optimal blending between different models and expert systems using deep machine learning methods. Clifton (2013) focuses on the turbine performance model using the machine-learning model (Clifton, 2013). Khan, Ali, and Mahmud (2014) suggest a model for prediction of the power generation of a wind-based power plant from a single hour up to a year (Khan, Ali, and Mahmud, 2014). Treiber, Heinermann, and Kramer (2016) proposed a model using a multitude of machine learning algorithms for short-term wind power prediction (Treiber, Heinermann, and Kramer, 2016). Perera, Aung, and Woon (2014) provide a survey on different machine learning techniques to predict the amount of power generated in the future (Perera, Aung, and Woon, 2014). Consequently, smart energy systems bring to the fore typical characteristics of big data scenarios.

This study aims to make a significant contribution to the literature. Firstly, a consolidated overview of big data in smart energy systems is devoted to the presentation of the internal architecture. Extensive mapping of the empirical literature (mostly big data analytics) on smart energy systems is provided for the 2015-2019 period, and the final part summarizes critical issues that have arisen in this paper.

\section{SMART ENERGY SYSTEMS AND RELATED CONCEPTS}

Smart energy systems were first mentioned as a term in 2009 that combines the series of management objectives, strategies, concepts, tasks, models, processes, mechanism, measures based on big data analytics and advanced information and communication technologies (ICTs), cloud computing, the internet of things to deal with the challenge of traditional energy systems and to supply progressively demand high quality and personalized energy products and services (Zhou, Yang, and Shen, 2017).

Smart energy systems focus on understanding energy consumers that deal with network load and consumption habits (Lund et al., 2017). Smart energy systems provide more accessible and economical solutions for the transformation into future renewable and sustainable energy solutions integrate the electricity, heating, cooling, industry, buildings, and transportation sector (Lund et al., 2017). Indeed these systems have multiplied in recent years, with sensors, communication, computation, and control capabilities through increased digitization and automation of the infrastructure for operational efficiency leading to high-volume, highvelocity data (Rusitschka and Curry, 2016).

The capacity of energy big data offers real value to energy consumers using smart meter and smart grid technologies. The smart grid is the primary phase, and the basic form of smart energy systems (Zhou, Yang, and Shen, 2017) and smart grid focuses on the electricity sector while smart energy systems cover more sectors (Lund et al., 2017). As a modern infrastructure smart grid can integrate information and energy flow, power generation and operation can be 
optimized in real-time, electricity demand can be accurately predicted, and comprehensive information can be extracted from big data (Zhou et al., 2014). Smart meters are running the distribution of power grids record and transmit time-dependent consumption information, including consumer information, to data centers (Koponen et al., 2008). A million smart meters can take part in the smart grid to produce big data on electricity consumption (Mohammad, 2018).

The 'smart' element of these energy systems refers to integrating energy flow, information flow, and business process flow (Lammers and Hoppe, 2019). Therefore, energy big data is composed of user description data, user behavior data, energy system data, and business systems related data (Zhou, Yang, and Shen, 2017). User description data contains the household data, demographic data, and residential characteristic data when user behavior data includes the marketing systems data, social media data, as well as others. Energy systems data involves energy production data and asset management data. Business systems related data refers to the characteristics of external data such as weather data, GIS data, and transportation data (Wen et al., 2018; Zhou and Yang, 2018). Notably, a typical smart meter contains the measurements such as node voltage, feeder current, power factor, active and reactive power, energy over a period, total harmonic distortion, load demand, and more (Zhang, Huang, and Bompard, 2018). A variety of smart meter analytics algorithms and applications have been proposed, mainly in the smart grid literature (Wang, Liu, and Guo, 2016). Therefore, each structure can be defined as a subunit interface in smart energy systems.

\subsection{Big Data Characteristics in Smart Energy}

Energy big data has five characteristics that are identified "5V": volume, velocity, variety, veracity, and value (Zhou et al., 2018).

Volume denotes the massive amount of data that is a challenge for storing and analyzing. Large-scale energy production and consumption data for obtaining valuable knowledge for industrial and research communities are collected by advanced measurement devices (Pei et al., 2017).

Variety of data identified different formats, types, and structures (structured, semi-structured, and unstructured) since energy big data are incredibly complicated and multi-dimension. Real-time data is generated by IoT technologies, and historical data is gathered open data from various sources, secondary data, and social media data (Marinakis et al., 2018).

Velocity refers to data processing speed to ensure real-time energy supply-demand balance and ad hoc queries (Wen et al., 2018). Errors in measurements of the data assessment and state estimation in smart systems may exist due to the imperfections in devices or mistakes in a variety of data transmission (Zhang, Huang, and Bompard, 2018). 
Veracity indicates the messiness, accuracy, or trustworthiness of the data (Zhang, Huang, and Bompard, 2018). Veracity is crucial in decision making based on various data entries collected to define actual conditions in energy.

Value refers to the knowledge discovery of energy big data to promote system reliability, to understand energy consumption patterns, to provide personalized energy efficiency services, and to develop competitive marketing strategies (Zhou, Fu, and Yang, 2016; Wen et al., 2018).

\subsection{Big Data Analytics}

Valuable information can be mined using energy big data through data analytics. The data analytics techniques are frequently used to extract valuable information from historical data and real-time data. Machine learning approaches and artificial intelligence have demonstrated promising to reveal the pattern of potential relations in the energy big data. Besides, data mining is a standard tool by which information can be discovered in big data analytics.

The massive data gathered from the smart meter and sensors are vulnerable to incomplete, inconsistent, and incorrect data; therefore, data preprocessing is executed to resolve such issues. Data visualization and data analytics are some of the main categories for deriving models that provide a clear action plan and solve the problem of supply and demand balances.

Research focuses on time-varying energy consumption data to generate consumption or load patterns identified as typical load profiles (Bedingfield et al., 2018). Typical load profiles are used for load forecasting, load estimation, load control, load disaggregation, abnormal electricity consumption detection, designing electricity tariff offers, developing market strategies, or demand-side response policy (Bedingfield et al., 2018). Also, transient stability analysis, electric device state estimation, power quality monitoring, topology identification, renewable energy forecasting, and non-technical loss detection are data analytics applications in big data (Zhang, Huang, and Bompard, 2018). This study highlights the applications of energy big data and gives a brief overview of smart energy systems to map the latest research trend.

\section{METHODS}

Articles published in English from 2015 to 2019 in the Web of Science database were searched. Search terms included smart energy, smart meter, smart grid, and smart energy systems with big data or energy big data. In this study, papers within smart energy systems that have been cited for big data analytics are reviewed.

Expert knowledge of the literature has also been used, and criteria of exclusion shown in Table 1 have been applied to determine the final set of articles for the full review.

Four hundred forty-four articles were initially imported for review based on the topic. Title and abstract review in English and selection of post-2015 data only are resulted in 138 papers 
that include commentary, opinion, or theoretical content. In Figure 1, these literature reviews are classified by year.

Table 1. Exclusion Criteria

\begin{tabular}{|c|c|}
\hline Exclusion criteria & Papers that were removed \\
\hline Energy big data & Papers not specifically concerned with smart energy systems and big data. \\
\hline Period & Any papers that collected empirical data before 2015 . \\
\hline Language & Papers that collected data from outside English language. \\
\hline $\begin{array}{l}\text { Empirical focus for full } \\
\text { text review }\end{array}$ & $\begin{array}{l}\text { Papers that contained only commentary, opinion or theoretical content. } \\
\text { Abstract-only papers for poster presentations at conferences, which did } \\
\text { not contain sufficient exposition of data. }\end{array}$ \\
\hline
\end{tabular}

According to Web of Science categories, 138 papers are mostly published in such fields: engineering electrical electronic (54), computer science and information systems (31), telecommunications (25), energy fuels (21). The volume distributions of publication based on countries/regions generate the result as 33\% China, \%25 USA, \%12 England, \%10 Australia, \%6 Canada, \%5 India, Taiwan, and South Korea, and others. The Agencies that fund the studies on big data in smart energy systems are predominantly from China.

All papers that are evaluated through the peer-reviewed publishing process are eliminated by criteria of exclusion. Of these, 114 papers are not an empirical study, so 24 articles are used for the review. These studies are organized according to the type of smart energy, data analysis, and big data characteristics based on $5 \mathrm{~V}$. The overall picture of the literature on big data in smart energy systems is depicted using this approach. 


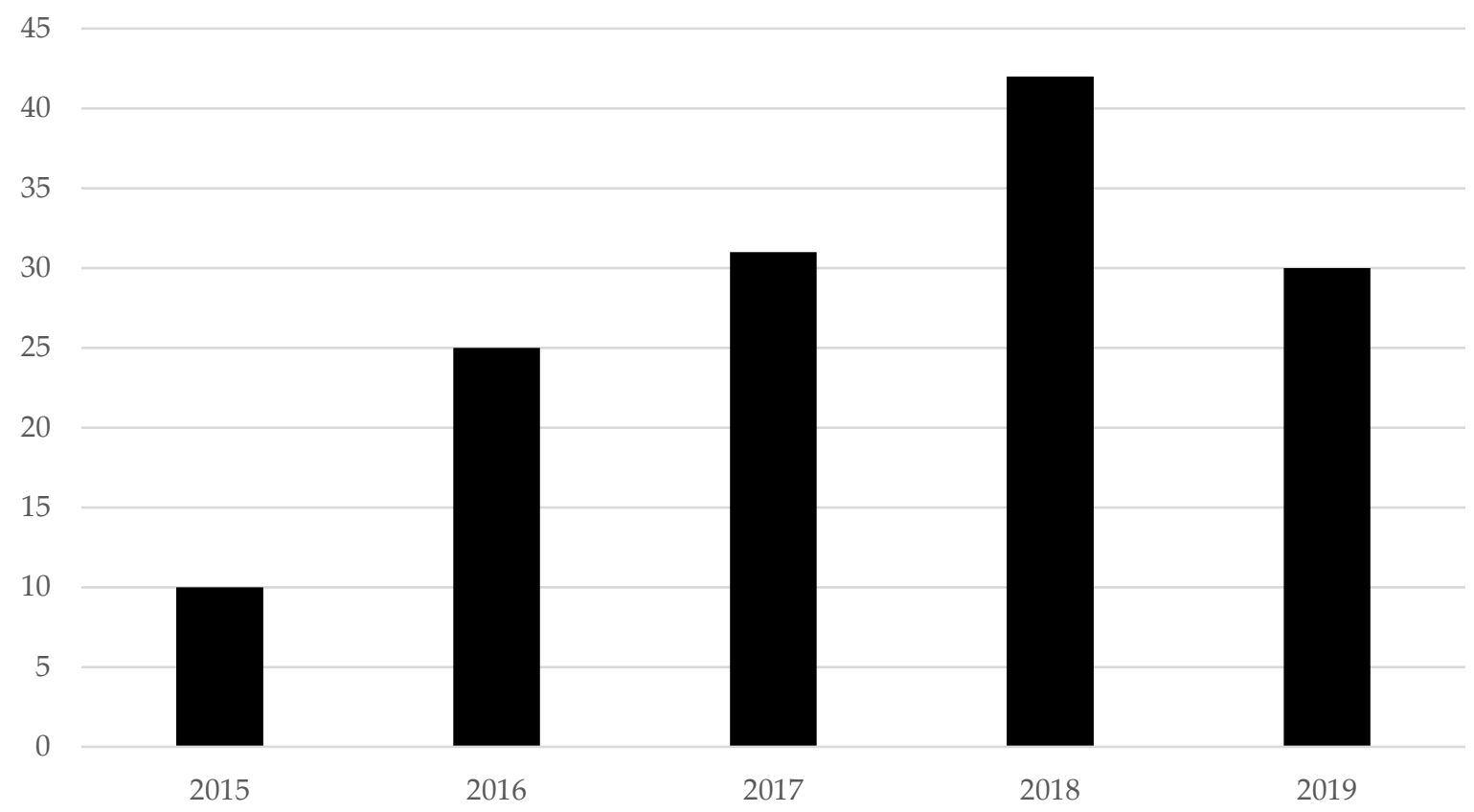

Figure 1. The number of publications on smart energy systems by year.

\section{RESULTS}

This research explores the empirical studies focused on big data in smart energy systems as it identifies the key indicators that emerged to be implemented in different fields. The key indicators of big data in smart energy are divided into eleven categories: authors, title, publication year, journal, the concept of smart energy systems, data analytics, the volume of data, variety of data, velocity of data, the veracity of data and value of data.

The information of authors and papers is related the researcher identification. Smart energy systems' related concepts can be indicated by the smart grid, smart meter, and smart energy. Data analytics is about detail in advance statistics, data mining, artificial intelligence, and machine learning. Volume (size of data), variety (structure, semi-structure, un-structure data), velocity (speed of data processing), veracity (data accuracy), and value (valuable information) of data are characteristics of big data.

The comprehensive information of manuscripts is shown in Table 2. The number of publications on the big data in smart energy systems distributes 4 manuscripts in 2015, 6 manuscripts in 2016, 1 manuscript in 2017, 9 manuscripts in 2018, and 4 manuscripts in 2019. In 2017, the publications on the big data in smart energy instantly decreased in the Web of Science database.

Generally, researchers emphasize the "smart" term in their studies title. "Big data" term is not frequently viewed in the title; however, keywords of manuscripts include big data and smart 
energy terms. These articles introduce and illustrate various concepts of smart energy systems such as smart meter and smart grid.

A smart meter is predominantly utilized to explain each case on big data in smart energy since advanced or smart metering systems' records consumption energy and other information to monitor and bill, usually in increments of minutes, such as 15-minute intervals, 30-minute intervals, and hourly intervals (Federal Energy Regulatory Commission, 2008). The amount of energy measured in $\mathrm{kWh}$ for a specific interval to determine the load profiling, load forecasting, fault detection for customers, which are residential, commercial, industrial, or transportation, is enhanced the diversity of research in this field. The volume of data is generated from a wide variety of data sources. According to this review, structure data is gathered from AMI and smart meter. In contrast, the unstructured data is an acquisition from the different database that is searchable and sortable to predict consumption patterns. The veracity of data based on specific machine learning algorithms, artificial intelligence, and hybrid methods is high due to big data analytics's ability. The information on the velocity of data is limited for the manuscripts that are readily accessible to review. The value of data relates to the increasing importance of big data analytics to reveal various applications in smart energy.

Energy big data is used in the context of consumption prediction, load forecasting, and load profiling, fault detection, production of data preprocessing, and demand response according to this study. Machine learning algorithms are dominantly utilized to extract the information in the mass of energy big data. In data analysis techniques, the capability of multi-resolution clustering, self-organizing map, K-means for clustering has their upper-class features to offer load profiling. Classification algorithms that endorse vector machine, neural network, regression trees, and time series are commonly used for prediction and forecasting. Artificial Intelligence and the statistical model are designed to make the most accurate predictions for fault detection. 
Table 2. Publications on Smart Energy Systems

\begin{tabular}{|c|c|c|c|c|c|c|}
\hline Articles & $\begin{array}{l}\text { Volume } \\
\text { of data }\end{array}$ & $\begin{array}{l}\text { Variety } \\
\text { of Data }\end{array}$ & $\begin{array}{l}\text { Velocity } \\
\text { of data }\end{array}$ & $\begin{array}{l}\text { Veracity } \\
\text { of data }\end{array}$ & $\begin{array}{l}\text { Value } \\
\text { of data }\end{array}$ & Data Analytics \\
\hline $\begin{array}{l}\text { Aman, } \\
\text { Simmhan and } \\
\text { Prasanna, } 2015\end{array}$ & $\begin{array}{l}\text { per } 15 \mathrm{~min} \text { in } 3 \\
\text { years }\end{array}$ & $\begin{array}{l}\text { Unstructured } \\
\text { Data (Electricity } \\
\text { Consumption } \\
\text { Data, Weather } \\
\text { and Schedule } \\
\text { Data) }\end{array}$ & & & $\begin{array}{l}\text { Consumption } \\
\text { prediction }\end{array}$ & $\begin{array}{l}\text { Machine Learning, Prediction Models } \\
\text { (ARIMA And Regression Tree) }\end{array}$ \\
\hline Maaß et al., 2015 & $30 \mathrm{~TB}$ & $\begin{array}{l}\text { Unstructured } \\
\text { Data (Full } \\
\text { Electrical Raw } \\
\text { Data) }\end{array}$ & $\begin{array}{l}19,35 \mathrm{GiB} \text { per } \\
\text { day }\end{array}$ & & $\begin{array}{l}\text { Data processing } \\
\text { in EDR }\end{array}$ & Statistics (Comparative Analysis) \\
\hline $\begin{array}{l}\text { Peppanen et al., } \\
2015\end{array}$ & & $\begin{array}{l}\text { Unstructured } \\
\text { Data (Power, } \\
\text { Voltage, Current } \\
\text { Data) }\end{array}$ & & $\begin{array}{l}\text { Accuracy rate } \\
97.28 \%\end{array}$ & $\begin{array}{l}\text { Distribution } \\
\text { system state } \\
\text { estimation } \\
\text { (DSSE) }\end{array}$ & $\begin{array}{l}\text { Statistics, Pseudo-Measurements } \\
\text { Generation And Advanced } \\
\text { Visualization }\end{array}$ \\
\hline $\begin{array}{l}\text { Zhang et al., } \\
2015\end{array}$ & $1.5 \mathrm{~TB}$ & $\begin{array}{l}\text { Unstructured } \\
\text { Data (Load and } \\
\text { Weather Data) }\end{array}$ & & $\begin{array}{l}\text { Relative error } \\
3 \%\end{array}$ & Load forecasting & Machine Learning, Cluster Analysis \\
\hline $\begin{array}{l}\text { Chou and Ngo, } \\
2016\end{array}$ & 50404 raw data & $\begin{array}{l}\text { Unstructured } \\
\text { Data (Smart } \\
\text { Meter Data and } \\
\text { Weather Data) }\end{array}$ & & & $\begin{array}{l}\text { Prediction of } \\
\text { building energy } \\
\text { consumption }\end{array}$ & $\begin{array}{l}\text { Machine Learning (Time Series and } \\
\text { Metaheuristic Optimization) }\end{array}$ \\
\hline $\begin{array}{l}\text { Kwac and } \\
\text { Rajagopal, } 2016\end{array}$ & $\begin{array}{l}58 \mathrm{k} \text { residential } \\
\text { households data }\end{array}$ & $\begin{array}{l}\text { Structure Data } \\
\text { (Smart Meter } \\
\text { Data) }\end{array}$ & & & $\begin{array}{l}\text { Demand } \\
\text { response }\end{array}$ & $\begin{array}{l}\text { Linear Response Modeling and a Novel } \\
\text { Heuristic Approach }\end{array}$ \\
\hline $\begin{array}{l}\text { Li, Li and Smith, } \\
2016\end{array}$ & $\begin{array}{l}6369 \text { customer's } \\
\text { data }\end{array}$ & $\begin{array}{l}\text { Structure Data } \\
\text { (Smart Meter } \\
\text { Data) }\end{array}$ & & & Load profiling & $\begin{array}{l}\text { Machine Learning (Multi-Resolution } \\
\text { Clustering (MRC) Method) }\end{array}$ \\
\hline $\begin{array}{l}\text { Anderson et al., } \\
2017\end{array}$ & & $\begin{array}{l}\text { Structure Data } \\
\text { (Census Data } \\
\text { Electricity } \\
\text { Consumption } \\
\text { Data) }\end{array}$ & & & $\begin{array}{l}\text { Load profiling, } \\
\text { household } \\
\text { composition, } \\
\text { and } \\
\text { characteristics }\end{array}$ & Statistics \\
\hline
\end{tabular}




\begin{tabular}{|c|c|c|c|c|c|c|}
\hline $\begin{array}{l}\text { Rodríguez } \\
\text { Fernández, } \\
\text { González } \\
\text { Alonso and } \\
\text { Zalama } \\
\text { Casanova, } 2016\end{array}$ & 5 petabytes & $\begin{array}{l}\text { Structure Data } \\
\text { (Consumption } \\
\text { Information } \\
\text { Data) }\end{array}$ & $4 h$ & $\begin{array}{l}\text { Accuracy rate } \\
75.83 \%\end{array}$ & $\begin{array}{l}\text { Online } \\
\text { identification of } \\
\text { appliances }\end{array}$ & $\begin{array}{l}\text { Machine Learning (Jubatus } \\
\text { Classifications) }\end{array}$ \\
\hline $\begin{array}{l}\text { Tong, Kang and } \\
\text { Xia, } 2016\end{array}$ & $829.32 \mathrm{MB}$ & $\begin{array}{l}\text { Unstructured } \\
\text { Data } \\
\text { (Household } \\
\text { Electricity } \\
\text { Consumption) }\end{array}$ & $\begin{array}{l}829.32 \mathrm{MB} / 3 \\
\text { hour }\end{array}$ & $\begin{array}{l}\text { Reconstruction } \\
\text { precision } 94.43 \%\end{array}$ & $\begin{array}{l}\text { Load data } \\
\text { compression }\end{array}$ & Data Compression \\
\hline $\begin{array}{l}\text { Munshi and } \\
\text { Mohamed, } 2017\end{array}$ & $\begin{array}{l}6436 \text { home and } \\
\text { business data }\end{array}$ & $\begin{array}{l}\text { Unstructured } \\
\text { Data (Electricity } \\
\text { Consumption, } \\
\text { Weather Data) }\end{array}$ & & & $\begin{array}{l}\text { Dynamic } \\
\text { demand } \\
\text { response }\end{array}$ & $\begin{array}{l}\text { Data Mining and Machine Learning } \\
\text { (Scalable Advanced Massive Online } \\
\text { Analysis) }\end{array}$ \\
\hline $\begin{array}{l}\text { Bedingfield et } \\
\text { al., } 2018\end{array}$ & $\begin{array}{l}175 \text { million } \\
\text { records }\end{array}$ & $\begin{array}{l}\text { Structure Data } \\
\text { (Smart Meter } \\
\text { Data) }\end{array}$ & & & Load profiling & $\begin{array}{l}\text { Machine Learning, Cluster Analysis } \\
\text { (Growing Self Organizing Map) }\end{array}$ \\
\hline Li et al., 2018 & $\begin{array}{l}490 \text { taxis within } \\
30 \text { days }\end{array}$ & $\begin{array}{l}\text { Structure Data } \\
\text { (Smart Meter } \\
\text { Data) }\end{array}$ & & MAPE is $4.14 \%$ & $\begin{array}{l}\text { Determination } \\
\text { of behavior \& } \\
\text { risk pattern }\end{array}$ & Stochastic Game Model \\
\hline $\begin{array}{l}\text { Chui, Lytras } \\
\text { and Visvizi, } \\
2018\end{array}$ & 1500 sample & $\begin{array}{l}\text { Structure Data } \\
\text { (Smart Meter } \\
\text { Data) }\end{array}$ & & $\begin{array}{l}\text { Overall } \\
\text { accuracy rate } \\
91.8 \%\end{array}$ & $\begin{array}{l}\text { Load } \\
\text { monitoring }\end{array}$ & $\begin{array}{l}\text { Hybrid Method (Hybrid Genetic } \\
\text { Algorithm Support Vector Machine } \\
\text { Multiple Kernel Learning) }\end{array}$ \\
\hline $\begin{array}{l}\text { Joseph and } \\
\text { Erakkath Abdu, } \\
2018\end{array}$ & $\begin{array}{l}9600 \text { data per } \\
\text { day }\end{array}$ & $\begin{array}{l}\text { Structure Data } \\
\text { (Smart Meter } \\
\text { Data) }\end{array}$ & & $\begin{array}{l}\text { mean squared } \\
\text { error is } 0.0029\end{array}$ & Load profiling & Optimization and Cluster Analysis \\
\hline $\begin{array}{l}\text { Li, Cursio and } \\
\text { Sun, } 2018\end{array}$ & $\begin{array}{l}392 \text { million } \\
\text { locational } \\
\text { marginal price } \\
\text { records }\end{array}$ & Structure Data & & & Price fluctuation & $\begin{array}{l}\text { Statistics (Principal Component } \\
\text { Analysis) }\end{array}$ \\
\hline $\begin{array}{l}\text { Mohamed et al., } \\
2018\end{array}$ & $\begin{array}{l}12 \text { customers } \\
\text { data, over a } \\
\text { period of } 365 \\
\text { day }\end{array}$ & $\begin{array}{l}\text { Structure Data } \\
\text { (Energy } \\
\text { Consumption } \\
\text { Data) }\end{array}$ & & $\begin{array}{l}\text { reduction rate } \\
55 \%\end{array}$ & $\begin{array}{l}\text { Data reduction } \\
\text { with cloud } \\
\text { computing and } \\
\text { AMI }\end{array}$ & Statistics, Data Reduction, Forecasting \\
\hline $\begin{array}{l}\text { Salami, } \\
\text { Movahedi }\end{array}$ & 10158 GB & $\begin{array}{l}\text { Unstructured } \\
\text { Data (Electricity }\end{array}$ & $\begin{array}{l}90.66 \text { second per } \\
\text { LOTD }\end{array}$ & $0.86-0.94$ & $\begin{array}{l}\text { Short-term } \\
\text { prediction of }\end{array}$ & $\begin{array}{l}\text { Artificial Intelligence based forecast } \\
\text { techniques }\end{array}$ \\
\hline
\end{tabular}




\begin{tabular}{|c|c|c|c|c|c|}
\hline $\begin{array}{l}\text { Sobhani and } \\
\text { Ghazizadeh, } \\
2018\end{array}$ & & $\begin{array}{l}\text { Consumption, } \\
\text { Weather Data) }\end{array}$ & & $\begin{array}{l}\text { electricity } \\
\text { supply and } \\
\text { demand. }\end{array}$ & \\
\hline $\begin{array}{l}\text { Shi, } \mathrm{Xu} \text { and Li, } \\
2018\end{array}$ & $\begin{array}{l}920 \text { smart meter } \\
\text { customer' data }\end{array}$ & $\begin{array}{l}\text { Unstructured } \\
\text { Data } \\
\text { (Consumed } \\
\text { Electricity, } \\
\text { Questionnaires) }\end{array}$ & $\begin{array}{l}\text { RSME for } \\
\text { ARIMA by } \\
19.5 \% \text {, SVM by } \\
13.1 \% \text { and } \\
\text { classical deep } \\
\text { RNN by } 6.5 \%\end{array}$ & Load forecasting & $\begin{array}{l}\text { Statistics, Deep Learning, Machine } \\
\text { Learning (Neural Network, Time Series) }\end{array}$ \\
\hline $\begin{array}{l}\text { Singh and } \\
\text { Yassine, } 2018\end{array}$ & $\begin{array}{l}25.2 \text { million } \\
\text { records }\end{array}$ & $\begin{array}{l}\text { Structure Data } \\
\text { (Smart Meter } \\
\text { Data) }\end{array}$ & $\begin{array}{l}\text { Accuracy rate } \\
81.89 \%\end{array}$ & Load forecasting & $\begin{array}{l}\text { Data Mining, Machine Learning, } \\
\text { Cluster Analysis (Support Vector } \\
\text { Machine (SVM) And Multi-Layer } \\
\text { Perceptron (MLP)) }\end{array}$ \\
\hline $\begin{array}{l}\text { Huang et al., } \\
2019\end{array}$ & $\begin{array}{l}96000 \text { data per } \\
\text { day; } 5088000 \\
\text { data per day, } \\
\text { and } 1122000 \\
\text { data per hour } \\
\text { for } 3 \text { cases }\end{array}$ & $\begin{array}{l}\text { Structure Data } \\
\text { (Smart Meter } \\
\text { Data) }\end{array}$ & $\begin{array}{l}\text { Accuracy rate } \\
\text { for case } \\
2: 91.64 \% \text { and } \\
\text { case } 3: 97.31 \%\end{array}$ & $\begin{array}{l}\text { Fault detection } \\
\text { and user } \\
\text { segmentation }\end{array}$ & Artificial Neural Network \\
\hline Wang et al., 2019 & $\begin{array}{l}4232 \text { residual } \\
\text { consumers over } \\
536 \text { days at an } \\
\text { interval of } \\
\text { 30min }\end{array}$ & $\begin{array}{l}\text { Structure Data } \\
\text { (Smart Meter } \\
\text { Data And Socio- } \\
\text { Survey for } \\
\text { Socio- } \\
\text { Demographic) }\end{array}$ & $\begin{array}{l}\text { Accuracy rate } \\
67.3 \% \text { and F1 } \\
\text { score } 0.622\end{array}$ & Load profiling & $\begin{array}{l}\text { Machine Learning, Deep Learning } \\
\text { (Convolutional Neural Network } \\
(\mathrm{CNN}))\end{array}$ \\
\hline Zahid et al., 2019 & 9314 records & $\begin{array}{l}\text { Structure Data } \\
\text { (Electricity } \\
\text { Consumption } \\
\text { Data) }\end{array}$ & $\begin{array}{l}\text { MAE for ECNN: } \\
1.38 \text { and ESVR: } \\
1.78\end{array}$ & $\begin{array}{l}\text { Load and price } \\
\text { forecasting }\end{array}$ & $\begin{array}{l}\text { Data Mining, Machine Learning, Deep } \\
\text { Learning (Enhanced Convolutional } \\
\text { Neural Network (ECNN), Enhanced } \\
\text { Support Vector Regression (ESVR)) }\end{array}$ \\
\hline $\begin{array}{l}\text { Zhang et al., } \\
2019\end{array}$ & 999932 raw data & $\begin{array}{l}\text { Structured Data } \\
\text { (Power } \\
\text { Consumption } \\
\text { Data) }\end{array}$ & & $\begin{array}{l}\text { Prediction of } \\
\text { abnormal power } \\
\text { consumption }\end{array}$ & Statistics (Mean Spectral Radius) \\
\hline
\end{tabular}




\section{CONCLUSION}

In this study, the big data in smart energy systems have been critically reviewed. These energy data have been gathered from smart systems and appliances, including smart meters, smart grid and smart power systems, energy consumption data, weather data, and schedule data. The primary motivation for using smart systems is to understand and solve the problems in conventional energy production and consumption phases based on big data analytics. Besides, the smart systems enable the minimization of energy by-products such as GHG emissions that are the main drivers of global climate change and minimize the total energy production and consumption costs. Between 2015 and August 2019, 138 studies were published and found in the Web of Science. There is an increasing tendency for big energy data issue amount scholars. The share of scientific disciplines is engineering electrical electronics (39\%), computer science and information systems (22\%), telecommunications (18\%), energy fuels (15\%), others (5\%). In terms of country and regional distribution of these studies, China and the USA are prominent countries. Among 138 publications, only 24 of them focused on empirical studies. Throughout this review, twenty-four empirical studies of data analytics are observed in the smart systems' five big data characteristics.

The systematic evaluation of each manuscript may be a 'living lab' of many different experiments based on data analytics. By applying machine learning algorithms and data mining, big data can be utilized to predict the energy consumption pattern and gain valuable insights from load profiling and load monitoring. Moreover, large swings in demand can be predicted by using load forecasting and extraction of consumption habits. AI, machine learning, data mining techniques, and big data can help climate change adaption policy and simultaneously match supply and demand.

According to this critical review, through understanding data pattern, big data can support long-term relationship inevitable to transform energy systems from fossil to renewable ones for sustainability. Studies among inter-disciplines are at the desired level to elaborate on the usage of smart energy systems throughout societies. Smart energy systems and their diffusion into other disciplines require further empirical and crosscutting studies.

\section{References}

Aman, S., Simmhan, Y. and Prasanna, V. K. (2015) ‘Holistic measures for evaluating prediction models in smart grids', IEEE Transactions on Knowledge and Data Engineering, 27(2), pp. 475-486. doi: 10.1109/TKDE.2014.2327022.

Anderson, B. et al. (2017) 'Electricity consumption and household characteristics: Implications for census-taking in a smart metered future', Computers, Environment and Urban Systems. doi: 10.1016/j.compenvurbsys.2016.06.003. 
'Annual Energy Outlook 2019' (2019). doi: DOE/EIA-0383(2012) U.S.

Bedingfield, S. et al. (2018) 'Multi-granular electricity consumer load profiling for smart homes using a scalable big data algorithm', Sustainable Cities and Society, 40, pp. 611-624. doi: 10.1016/j.scs.2018.04.006.

Chou, J. S. and Ngo, N. T. (2016) 'Time series analytics using sliding window metaheuristic optimization-based machine learning system for identifying building energy consumption patterns', Applied Energy, 177, pp. 751-770. doi: 10.1016/j.apenergy.2016.05.074.

Chui, K. T., Lytras, M. D. and Visvizi, A. (2018) 'Energy sustainability in smart cities: Artificial intelligence, smart monitoring, and optimization of energy consumption', Energies, 11(11), p. 2869. doi: 10.3390/en11112869.

Clifton, A. (2013) Using Machine Learning to Create Turbine Performance Models. National Renewable Energy Lab.(NREL), Golden, CO (United States), 2013.

Climate Transparency (2018) Brown to Green: the G20 Transition to A Low-Carbon Economy.

Ebinger, J. and Vergara, W. (2011) Climate Impacts on Energy Systems. The World Bank. doi: 10.1596/9780-8213-8697.

EEA (2019) Energy and climate change. Available at: https://www.eea.europa.eu/signals/signals2017/articles/energy-and-climate-change (Accessed: 3 January 2020).

GCF (2019) Green Climate Fund. Available at: https://www.greenclimate.fund/mwginternal/de5fs23hu73ds/progress?id=qt1rnb1dSS9YVz1pGtR0TDXCLexQeB4NKzFJqBzpUKo, \&dl (Accessed: 3 January 2020).

Huang, X. et al. (2019) 'Electric load data compression and classification based on deep stacked autoencoders', Energies, 12(4), p. 653. doi: 10.3390/en12040653.

Joseph, S. and Erakkath Abdu, J. (2018) 'Real-time retail price determination in smart grid from realtime load profiles', International Transactions on Electrical Energy Systems, 28(3), p. e2509. doi: 10.1002/etep.2509.

Jucikas, T. (2017) Artificial Intelligence and the future of energy. Available at: https://medium.com/wepower/artificial-intelligence-and-the-future-of-energy-105ac6053de4 (Accessed: 24 October 2019).

Khan, G. M., Ali, J. and Mahmud, S. A. (2014) ‘Wind power forecasting - An Application of Machine Learning in Renewable Energy', in 2014 International Joint Conference on Neural Networks (IJCNN). IEEE, pp. 1130-1137. doi: 10.1109/IJCNN.2014.6889771.

Koponen, P. et al. (2008) Definition of Smart Metering and Applications and Identification of Benefits, 
Intelligent Energy.

Kwac, J. and Rajagopal, R. (2016) 'Data-driven targeting of customers for demand response', IEEE Transactions on Smart Grid, 7(5), pp. 2199-2207. doi: 10.1109/TSG.2015.2480841.

Lammers, I. and Hoppe, T. (2019) 'Watt rules? Assessing decision-making practices on smart energy systems in Dutch city districts', Energy Research and Social Science. Elsevier, 47(January 2018), pp. 233-246. doi: 10.1016/j.erss.2018.10.003.

Li, C. et al. (2018) 'Data-Driven Charging Strategy of PEVs under Transformer Aging Risk', IEEE Transactions on Control Systems Technology, 26(4), pp. 1386-1399. doi: 10.1109/TCST.2017.2713321.

Li, K., Cursio, J. D. and Sun, Y. (2018) ‘Principal component analysis of price fluctuation in the smart grid electricity market', Sustainability (Switzerland), 10(11), p. 4019. doi: 10.3390/su10114019.

Li, R., Li, F. and Smith, N. D. (2016) 'Multi-Resolution Load Profile Clustering for Smart Metering Data', IEEE Transactions on Power Systems, 31(6), pp. 4473-4482. doi: 10.1109/TPWRS.2016.2536781.

Lund, H. et al. (2017) 'Smart energy and smart energy systems', Energy. doi: 10.1016/j.energy.2017.05.123. Maaß, H. et al. (2015) 'Data processing of high-rate low-voltage distribution grid recordings for smart grid monitoring and analysis', EURASIP Journal on Advances in Signal Processing. SpringerOpen, 2015(1), p. 14. doi: 10.1186/s13634-015-0203-4.

Marinakis, V. et al. (2018) 'From big data to smart energy services: An application for intelligent energy management', Future Generation Computer Systems. Elsevier B.V. doi: 10.1016/j.future.2018.04.062.

Mohamed, M. F. et al. (2018) 'Data reduction in a cloud-based AMI framework with service-replication', Computers and Electrical Engineering, 69, pp. 212-223. doi: 10.1016/j.compeleceng.2018.02.042.

Mohammad, R. (2018) 'AMI Smart Meter Big Data Analytics for Time Series of Electricity Consumption', in 2018 17th IEEE International Conference On Trust, Security And Privacy In Computing And Communications/ 12th IEEE International Conference On Big Data Science And Engineering (TrustCom/BigDataSE). IEEE, pp. 1771-1776. doi: 10.1109/TrustCom/BigDataSE.2018.00267.

Munshi, A. A. and Mohamed, Y. A. R. I. (2017) ‘Big data framework for analytics in smart grids’, Electric Power Systems Research, 151, pp. 369-380. doi: 10.1016/j.epsr.2017.06.006.

Pei, X. et al. (2017) 'The PSMP-CCR2 interactions trigger monocyte/macrophage-dependent colitis /631/154/51/1568 /631/250/98 /13/21 /13/1 /13/31/38/77 /64/60 /82/51 /13 article', Scientific Reports, 7(1). doi: 10.1038/s41598-017-05255-7.

Peppanen, J. et al. (2015) 'Leveraging AMI Data for Distribution System Model Calibration and Situational Awareness', IEEE Transactions on Smart Grid, 6(4), pp. 2050-2059. doi: 
10.1109/TSG.2014.2385636.

Perera, K. S., Aung, Z. and Woon, W. L. (2014) 'Machine Learning Techniques for Supporting Renewable Energy Generation and Integration: A Survey', in, pp. 81-96. doi: 10.1007/978-3-319-13290-7_7.

Rodríguez Fernández, M., González Alonso, I. and Zalama Casanova, E. (2016) ‘Online identification of appliances from power consumption data collected by smart meters', Pattern Analysis and Applications, 19(2), pp. 463-473. doi: 10.1007/s10044-015-0487-x.

Rusitschka, S. and Curry, E. (2016) 'Big Data in the Energy and Transport Sectors', in New Horizons for a Data-Driven Economy. Cham: Springer International Publishing, pp. 225-244. doi: 10.1007/9783-319-21569-3_13.

Salami, M., Movahedi Sobhani, F. and Ghazizadeh, M. (2018) 'Short-Term Forecasting of Electricity Supply and Demand by Using the Wavelet-PSO-NNs-SO Technique for Searching in Big Data of Iran's Electricity Market', Data, 3(4), p. 43. doi: 10.3390/data3040043.

Shi, H., Xu, M. and Li, R. (2018) ‘Deep Learning for Household Load Forecasting-A Novel Pooling Deep RNN', IEEE Transactions on Smart Grid, 9(5), pp. 5271-5280. doi: 10.1109/TSG.2017.2686012.

Singh, S. and Yassine, A. (2018) 'Big data mining of energy time series for behavioral analytics and energy consumption forecasting', Energies, 11(2), p. 452. doi: 10.3390/en11020452.

SRU (2011) Pathways Towards a 100\% Renewable Electricity System.

The Conversation (2018) Winds of change: Britain now generates twice as much electricity from wind as coal. Available at: https://theconversation.com/winds-of-change-britain-now-generates-twice-asmuch-electricity-from-wind-as-coal-89598 (Accessed: 2 March 2020).

Tong, X., Kang, C. and Xia, Q. (2016) 'Smart Metering Load Data Compression Based on Load Feature Identification', IEEE Transactions on Smart Grid, 7(5), pp. 2414-2422. doi: 10.1109/TSG.2016.2544883.

Treiber, N. A., Heinermann, J. and Kramer, O. (2016) 'Wind Power Prediction with Machine Learning', in, pp. 13-29. doi: 10.1007/978-3-319-31858-5_2.

Wang, Y. et al. (2019) ‘Deep learning-based socio-demographic information identification from smart meter data', IEEE Transactions on Smart Grid, 10(3), pp. 2593-2602. doi: 10.1109/TSG.2018.2805723.

Wang, Z., Liu, M. and Guo, H. (2016) 'A strategic path for the goal of clean and low-carbon energy in China', Natural Gas Industry B. Elsevier Ltd, 3(4), pp. 305-311. doi: 10.1016/j.ngib.2016.12.006.

Wen, L. et al. (2018) 'Compression of smart meter big data: A survey', Renewable and Sustainable Energy Reviews, 91, pp. 59-69. doi: 10.1016/j.rser.2018.03.088. 
Zahid, M. et al. (2019) 'Electricity price and load forecasting using enhanced convolutional neural network and enhanced support vector regression in smart grids', Electronics (Switzerland), 8(2), p. 122. doi: 10.3390/electronics8020122.

Zhang, P. et al. (2015) 'Short-term load forecasting based on big data technologies', CSEE Journal of Power and Energy Systems, 1(3), pp. 59-67. doi: 10.17775/CSEEJPES.2015.00036.

Zhang, Q. et al. (2019) 'Anomaly detection based on random matrix theory for industrial power systems', Journal of Systems Architecture, 95, pp. 67-74. doi: 10.1016/j.sysarc.2019.01.008.

Zhang, Y., Huang, T. and Bompard, E. F. (2018) ‘Big data analytics in smart grids: a review', Energy Informatics. SpringerOpen, 1(1), p. 8. doi: 10.1186/s42162-018-0007-5.

Zhou, K., Fu, C. and Yang, S. (2016) `Big data driven smart energy management: From big data to big insights', Renewable and Sustainable Energy Reviews. Elsevier, 56(2016), pp. 215-225. doi: 10.1016/j.rser.2015.11.050.

Zhou, K., Yang, C. and Shen, J. (2017) `Discovering residential electricity consumption patterns through smart-meter data mining: A case study from China', Utilities Policy, 44, pp. 73-84. doi: 10.1016/j.jup.2017.01.004.

Zhou, K. and Yang, S. (2018) Smart Energy Management, Comprehensive Energy Systems. doi: 10.1016/B9780-12-809597-3.00525-3.

Zhou, X. et al. (2018) 'Research Review on Big Data of the Smart Grid', in 2018 IEEE International Conference on Mechatronics and Automation (ICMA). IEEE, pp. 2030-2035. doi: 10.1109/ICMA.2018.8484631.

Zhou, Y. et al. (2014) 'Scenario analysis of energy-based low-carbon development in China', Journal of Environmental Sciences (China). Elsevier B.V., 26(8), pp. 1631-1640. doi: 10.1016/j.jes.2014.06.003. 